\title{
ПИТАњЕ КОГНИТИВНИХ ПРЕДНОСТИ БИЛИНГВИЗМА
}

\begin{abstract}
У раду је дат основни преглед досадашњих релевантних истраживања о когнитивним предностима билингвизма. Уочено је да су погледи на билингвизам најпре били негативни, тј. сматрало се да је ометао когнитивни развој детета, али касније му је призната когнитивна предност, нарочито у погледу извршних функција, попут инхибиције и контролисања пажње, као и радне меморије. У тим истраживањима показано је и да билингвизам има трајно позитиван утицај на очување когнитивних способности у каснијем животном добу. У раду је представљено и скорашње опречно мишљење о предности билингвизма, настало након метаанализе истраживања која предност наводно доказују.
\end{abstract}

Кључне речи: билингвизам, когнитивне предности, лингвистичке компетенције, старење

\section{1. Увод}

Предмет рада је основни преглед досадашњих релевантних истраживања о когнитивним предностима билингвизма. Билингвизам, односно двојезичност се дефинише као „способност за говорење два језика" (KRISTAL 1985). Данас је више од половине светске популације билингвално, а у Северној Америци свака пета особа говори још један језик код куће, поред енглеског, док су у Европи више од 50 посто људи билингвали (BIJALISTOK, KREJK i dr. 2013). Самим тим, интересовање за поређење когнитивних способности монолингвала и билингвала такође је порасло у последњих неколико деценија. Истраживања су показала да се функционисање, развој и опадање когнитивних способности између монолингвала и билингвала ипак разликују. Наиме, у истраживањима о билингвизму с једне стране се говори о предностима билингвизма, нарочито у погледу извршних функција (енгл. executive functions), као што су радна меморија, контрола пажње и инхибиције. Такође, те предности се

1 anakrsticka94@gmail.com 
испољавају и у каснијем животном добу, умањујући ефекте когнитивног слабљења. С друге стране, у новије време се преиспитују те когнитивне предности и отвара се дебата да ли је та предност заиста релевантних размера у односу на монолингвале, или су у питању неки други (често и спољашњи) фактори.

Циљ рада је да се стекне општи увид у водеће закључке и ставове истраживача о когнитивним предностима, али и о лингвистичким недостацима билингвала у односу на монолингвале, нарочито у раном когнитивном и лингвистичком развоју. Такође, изводе се општи закључци и о когнитивним предностима старијих билингвала.

\section{2. Релевантна ранија запажања и ставови о билингвизму кроз историју}

Истраживања су до пре педесетак година указивала на то да билингвизам има негативан утицај на развој ума. Сматрало се да учење два језика збуњује ум детета и да ће нужно довести до менталне ретардације код деце која су усвојила више језика (GUDENOU 1926). Владало је опште мишљење да ће билингвали имати ужи лексички фонд, успорене когнитивне способности и да ће улагати много више енергије да би правилно усвојили два језика. Билингвизам је увек био помињан кроз синтагме „проблем билингвизма” и „хендикепирајући утицај билингвизма” (DARSI 1963). Хакута и Дијаз су свом истраживању (1985) показали да су билингвали били слабији на тестовима интелигенције од монолингвалних вршњака.

Међутим, радикално другачије мишљење о когнитивном значају билингвизма изнели су Пеал и Ламберт (1962), испитујући паралелно децу која су била енглески монолингвали и децу која су била францускоенглески билингвали у Монтреалу. Претпоставили су да ће билингвали имати ниже оцене на скали вербалних мера интелигенције, али да ће имати исте резултате као монолингвали на скали невербалних мера. Њихови резултати су заправо били контрадикторни и почетној претпоставци и претходним теоријама о билингвизму. Билингвална деца су била боља од монолингвалне на већини тестова, нарочито оних који су захтевали манипулацију симбола и реорганизацију. Закључак је био да билингвална деца испољавају појачану „менталну флексибилност”, која је неопходна за промену употребе језика (PEAL i LAMBERT 1962). Отад је у когнитивним лингвистичким истраживањима окренут смер од негативног ка позитивном утицају билингвизма на развој когнитивних способности.

Мада је утврђен позитиван утицај билингвизма на когнитивне и лингвистичке процесе, постављало се питање на који начин се тај утицај одвија. Почетна истраживања о утицају билингвизма су износила конзервативну претпоставку да би се било какви утицај лингвистичког 
искуства нашао у домену лингвистичких компетенција (BIJALISTOK i KREJK 2010: 19). Током седамдесетих и осамдесетих истраживачи су долазили до закључака о значајнијој предности билингвалне деце у односу на монолингвалну у погледу решавања лингвистичких проблема заснованих на металингвистичкој свести ${ }^{2}$. Билингвали су лакше прихватали да је језик процес (ŽENG 2018: 2) и боље решавали невербалне проблеме који су изискивали инхибицију редундантних информација (JANKOVORAL 1972).

Бијалисток (1988) и Кромдал (1999) су испитивали металингвистичку свест и утврдили су да монолингвална и билингвална деца једнако добро препознају граматичке омашке у иначе смисленим реченицама, што је класичан начин мерења металингвистичких функција код деце. Међутим, када су реченице биле семантички аномаличне, тада је било потребно игнорисати погрешно значење и фокусирати се само на граматику, у чему су бољи били билингвали. Закључак је да им у томе није помогло додатно лингвистичко искуство, већ неки процеси који омогућавају приступ лингвистичком знању. Стога је уочено да није у толикој мери металингвистичко знање то које представља билингвалну предност, већ појачана пажња при селекцији и инхибицији језичке информације, које су препознатљиве компоненте извршних функција.

\section{3. Ефекти билингвизма на когнитивни развој}

Докази да билингвална деца имају одређене предности у односу на монолингвалну децу налазе се у промени фокуса испитивања ефекта билингвизма са лингвистичких задатака на когницију (ADESOPE, LAVIN i dr. 2010). Већина задатака који упућују на постојање билингвалне предности су маркери извршних функција (ŽENG 2018: 2). Развој система извршних функција ${ }^{3}$ је пресудно когнитивно достигнуће у раном детињству (BIJALISTOK I KREJK 2010: 20), јер тада деца постепено усваjају способност контролисања пажње, инхибиције ометајућих информација, надгледања стимулуса, повећавања радне меморије. Истраживања су показала да ефекти билингвизма остављају позитиван утицај на цео когнитивни систем и током целог животног века (BIJALISTOK і KREJK 2010; BEST, MILER i dr. 2011).

Испитивање позитивног деловања билингвизма на извршне функције се обично огледа у поређењу одговора монолингвала и билингвала на задатке који су наизглед слични, али увек је садржан још један

2 Металингвистичка свест (енгл. metalinguistic awareness) подразумева експлицитно знање о лингвистичкој структури и могућност да јој се приступи свесно (BIJALISTOK I KREJK 2010: 19).

3 Налази се у префронталном кортексу. 
додатни услов, који захтева неки облик извршног контролисања. Један од честих начина мерења извршног функционисања је такозвани задатак сортирања карата са условом промене димензије (енгл. Dimension Change Card Sort task (DCCS)) (ZELAZO, FRAJ I dr. 1996). Бијалисток је са својим колегама истраживачима овај задатак дала деци узраста од четири до пет година, којој је задато да распореде карте или по боји, или облику дијаграма на картама. Учесници прво распоређују по једној димензији (нпр. боја), па се тражи распоређивање по другој димензији (нпр. облику). Како се код деце испод пет година генерално јавља такозвана истрајност (енгл. perservation), односно немогућност прилагођавања промени правила, она би врло често наставила да слажу карте по боји, иако ново правило тражи слагање по облику. Да би задатак био успешно решен, неопходно је да се пажња преусмери са почетне на нову димензију, а да се почетна инхибира. Показало се да су управо билингвали били успешнији у том прилагођавању промени правила, што значи да им је извршно контролисање на вишем нивоу од монолингвала (BIJALISTOK 1999; BIJALISTOK i MARTIN 2004; OKANDA, MORIGUČI i dr. 2010).

Још један вид провере извршног функционисања јесте задатак уграђених фигура (енгл. Children's Embedded Figures Task), у ком је већина шестогодишње деце слично проналазила скривени облик, али билингвали су лакше мењали своју интерпретацију двосмислене фигуре, што је захтевало инхибицију првобитног значења стимулуса (BIJALISTOK I ŠAPERO 2005).

Међутим, у истраживањима која се тичу одговарања на конфликтне услове врло често се примењују Струп и фленкер задаци (енгл. Stroop task, flanker task). У првом је потребно именовати боју којом је реч написана, а да се притом игнорише значење саме речи. Када је значење било конфликтно са термином боје, показано је да су билингвали били успешнији од монолингвала у игнорисању ирелевантног обележја стимулуса (BIJALISTOK, KREJK i dr. 2008a). С друге стране, најчешћи облик фленкер задатка је задатак мреже пажње (енгл. Attentional Network Task (ANT)) (RUEDA i dr. 2004), у коме је деци представљено пет риба и задато им је да идентификују у ком смеру плива средња риба, при чему четврта фленкер риба може да упућује на исти смер као и циљна риба (конгруентни случај), или на обрнути (неконгруентни случај). Билингвали су реаговали брже и тачније него монолингвали у овом задатку (KOSTA, HERNANDEZ i dr. 2008); показали су предност и у конгруентном и у неконгруентном случају, а како за конгруентни није потребна инхибиција, долази се до закључка да постоји још један извор билингвалне предности, а то је надгледање (енгл. monitoring) (HILČI I KLAJN 2011). Оно обухвата инхибицију, али и пребацивање (енгл. shifting), с обзиром на то да 
ирелевантне податке и одговоре треба потиснути током пребацивања с једне опције на другу.

Још један аспект надгледања представља радну меморију (ŽENG 2018: 4), јер она треба да задржи одређено правило или шаблон неке серије поступака (ENGEL DE ABRU 2011). Резултати су подељени у вези са разликом између радне меморије билингвала и монолингвала, односно под одређеним условима појачана је код билингвала, а под одређеним није.

Истраживања у вези са теоријом ума (енгл. Theory of Mind) такође су препознала когнитивне предности билингвала у односу на монолингвале приликом решавања задатака (GEC 2003). Мада извршно функционисање игра улогу у теорији манифестације ума, домен његових утицаја је још увек нејасан, и посматра се више холистички него као рашчлањено на компоненте (инхибицију, смењивање, радну меморију), јер није увек сасвим јасно који механизам преовладава (ŽENG 2018: 4).

Из досадашњих резултата у литератури о предностима билингвизма предлаже се да билингвали поседују појачане извршне функције захваљујући међусобном надметању језика у њиховој паралелној активацији код билингвала. Међутим, два запажања се косе с овом тврдњом. Прво запажање упућује на то да се и код монолингвала јавља лингвистички конфликт (нпр. у семантички сродним речима), али се сматра да он не утиче на извршне функције (MIJAKE i FRIDMAN 2012). Друго запажање тиче се новорођенчади, која још увек имају неразвијене језичке репрезентације, али упркос томе се језичке способности седмомесечне монолингвалне и билингвалне новорођенчади разликују (KOVAČ i MELER 2009). У једном експерименту су бебама задати снимци без тона, у којима лица читају на језицима који се смењују и показано је да су бебе из билингвалне средине опажале промену језика, чак иако нису раније том језику биле изложене (SEBASTIJAN-GALES, ALBAREDA-KASTELOT i dr. 2012). Ово истраживање упућује на опште когнитивне предности билингвала, односно да рана изложеност већем броју језика утиче на пажњу још у раном животном добу. Самим тим, ове стратегије које појачавају процесирање пажње могу довести до јединственог система у ком су инкорпорирана два или више језика (BIJALISTOK, KREJK i dr. 2013). То би онда значило да извршно функционисање мора да активира и усмери пажњу на одређени језик, што се коси са претпоставком да је нециљни језик само инхибиран. Новорођенчад не разрешава паралелну активацију међу лексичким обележјима, већ гради и активира организоване схеме, које селектују језичку информацију током процесирања (ŽENG 2018: 5).

Исти закључци у вези са новорођеним билингвалима су у истраживањима која заступају предност билингвизма приписивани и од- 
раслим билингвалима, јер, као што новорођенчад привлаче разлике међу језицима, тако се и одрасли фокусирају на контрастирање одлика двају или више језика којима се служе. Стога билингвална предност може лежати у способности да пажња усмери на оба језика, а не у инхибицији једног од истовремено активираних система (ŽENG 2018: 6).

\section{4. Лингвистичке способности билингвала кроз призму извршног контролисања}

Лингвистичке способности билингвала нису потпуно позитивне. Наиме, истраживања у вези са знањем вокабулара показују ниже резултате билингвала у односу на монолингвале и то у више старосних доби (BIJALISTOK 2001). Такође, испитивања у вези са процесирањем језика код одраслих упућују да билингвали заостају у задацима који захтевају брз приступ лексемама и повраћај лексема. Они су спорији и праве више грешака при именовању, чак и у свом доминатном језику, слабији су у задацима вербалне флуентности, чешће им се дешавају ситуације „на врх језика” (енгл. tip-of-the-tongue) и чешће им се јављају интерференције у одабиру лексема (MAJKL i GOLAN 2005).

Поставља се питање да ли позитивни и негативни утицаји билингвизма истовремено постоје у једној истој индивидуи и ако да, да ли су ти утицаји независни или интерактивни (BIJALISTOK і KREJK 2010: 21). Да би дала одговор на први део питања, Бијалисток је са колегама истраживачима (2008a) радила истраживање са четири групе испитаника: млађих (20-30 година) и старијих (60-80 година) монолингвала и билингвала, који је требало да решавају задатке који су се тицали или језичке флуентности и доступности лексема, или невербалног извршног функционисања. Према резултатима, монолингвали су били бољи у прва два типа задатака, а билингвали у трећем типу, што наводи на закључак да су лексички и извршни процеси независни, мада су у другим задацима често комбиновани, јер процесирање језика захтева и извршно контролисање (BIJALISTOK і KREJK 2010: 21).

Ситуације комбиновања процеса су такође испитиване и поређиване међу монолингвалима и билингвалима. Један такав пример је задатак ослобађања из проактивне интерференције, у ком треба да се испитаници присете ставки из сукцесивно представљених листа речи, које припадају истој семантичкој категорији. Са сваком новом листом расте интерференција, а четврта представља другачију семантичку категорију. Извршно контролисање се овде спроводи кроз могућност да се испитаник фокусира на тренутну листу и да енкодира и поврати одређену лексичку јединицу. Показало се да су и билингвална деца и одрасли билингвали били бољи од монолингвала, иако су били слабији на тестирању 
вокабулара (BIJALISTOK i FENG 2009).

Разлика у нивоима језичке флуентности и извршног контролисања се одлично види кроз два подтипа теста вербалне флуентности (BIJALISTOK і KREJK 2010: 21). Први подтип тиче се условљености семантичком флуентношћу, у коме је потребно да се за један минут генеришу речи које припадају одређеној категорији, и захваљујући организационом принципу лингвистичке репрезентације ${ }^{4}$, одговори нуде увид у обимност вокабулара и језичку флуентност. Други подтип односи се на условљеност флуентности словом, у коме учесници треба да генеришу речи које почињу одређеним словом, али под одређеним рестрикцијама (без властитих имена, без бројева, без варијација исте речи). Овај подтип подразумева укључивање и језичке флуентности и извршног контролисања. Како билингвали обично имају мањи вокабулар од монолингвала, они генеришу мањи број речи него монолингвали у првом подтипу, али бољи су у другом подтипу. Међутим, Бијалисток, Крејк и Лук (2008b) утврдили су да су билингвали који су усавршили вокабулар генерисали више речи него и монолигвали и билингвали којима је вокабулар неусавршен, што значи да када се превазиђе препрека вокабулара, извршно контролисање доминира као билингвална предност.

С друге стране, скорашња истраживања (PAP i dr. 2015) су имала другачији приступ билингвизму у погледу извршних функција. Утврђено је да су резултати предности билингвизма заправо били ниских вредности, те да су предности биле веће када је узорак испитаника био мањи. Међутим, ово истраживање не пориче предност билингвала комплетно, већ истиче да може постојати код одређених индивидуа или група билингвала, који су почели да усвајају други језик у неком кључном узрасту. Једно новије истраживање (PAP i dr. 2017) показује пак више доказа против билингвалне предности. Изнова је анализирана сто једна ранија студија у вези са временом реакције и интерференцијом, при чему су студије укључивале Сајмонов тест, фленкер, Струп тест, или тест мреже пажње. Међу студијама са мањим бројем испитаника нађена је далеко већа предност у брзини реакције билингвала у односу на монолингвале, него што је то случај у студијама са већим бројем испитаника, што је непоуздан доказ у корист предности билингвизма. Као један од разлога зашто је тако тешко тестирати хипотезу предности билингвизма наводи се комплексност конструкта извршних функција (РАР 2019). У метаанализи (РАР i dr. 2015) показано је да одређен је број резултата у корист билингвизма проблематичан јер занемарује конфундирајуће факторе, при чијем отклањању, како је и доказано (PAP i dr. 2014, 2015), дешава се да се након поновљеног тестирања не добијају исти резултати.

4 Налази се у префронталном кортексу. 
Мада ова новија метааналитичка испитивања не поричу сасвим услове за могућу билингвалну предност, оно што се сматра непроменљивим је велики број људи који себе сматрају билингвалима, али не показују предности у извршним функцијама у односу на оне који себе сматрају монолингвалима (РАР 2019).

Пап (2019) такође тврди да заиста постоји нека врста структуралне и функционалне адаптације мозга кроз билингвално искуство. Нервно процесирање код билингвала и монолингвала јесте другачије када извршне функције обављају одређене задатке и нервне мреже су реорганизоване у мозгу који координира два језика, али то не значи нужно и да је обављање задатака боље у случају билингвизма. Оно што је важно јесте то да нервне разлике морају бити усклађене са бихевиоралним разликама, а оне се једино могу проценити да бихевиоралном нивоу (HILČI i KLAJN (2011).

У корист преиспитивања билингвалних предности јављају се и размишљања о ефекту културе као једном од фактора који илуструју искуствену страну језика (SEMJUEL, RUER BRAKIN i dr. 2018).

\section{5. Билингвизам и старење - когнитивне предности током живота}

Посебно интересовање за предности билингвизма јавља се кроз проучавање превентивних одлика билингвизма да би се спречило слабљење когнитивних способности у старости. Уочено је да билингвизам може да умањи деловање когнитивног старења, на основу тога што је слабљење контролисане пажње било мање код старијих билингвала него код њихових монолингвалних вршњака (BIJALISTOK, KREJK i dr. 2004). И старији билингвали су били бољи у задацима који захтевају промену правила и инхибирање нерелевантне информације, као што је био случај и са децом билингвалима (BIJALISTOK 2006).

У контексту деменције и слабљења когнитивних способности, говори се о когнитивном очувању (енгл. cognitive reserve), односно заштити од когнитивног слабљења, која проистиче из активног ангажовања у стимулативним интелектуалним, социјалним и физичким активностима (STERN 2002). Ову претпоставку су Бијалисток, Крејк и Фридман (2007) тестирали на монолингвалним и билингвалним вршњацима са деменцијом и утврдили да се деменција јавила четири године касније код билингвала у односу на монолингвале. То значи да билингвизам само одлаже и успорава симптоме Алцхајмера и сличних облика деменције, али их не спречава комплетно.

Да билингвизам може да успори когнитивно слабљење, најбоље се види преко извршног функционисања, а један од експеримената рађених на старијим билингвалима био је експеримент у коме се мери 
време реакције под одређеним условима (BIJALISTOK, KREJK i dr. 2004). Најпростији услов подразумевао је да се притисне једна од две боје на екрану. У нешто компликованијем услову боја се појављивала или са конгруентне или са неконгруентне стране дугмета за притискање. Време које је потребно да се одговори на задатак у неконгруентној ситуацији насупрот конгруентној зове се Симонов ефекат (BIJALISTOK і KREJK 2010: 20). Што је Симонов ефекат већи, то упућује на све већу потешкоћу у потискивању нерелевантне спацијалне информације, у чему су се пак старији билингвали показали као напреднији од монолингвалних вршњака. Закључак је био да билингвизам штити од когнитивног слабљења барем у способностима да се инхибирају ометајући утицаји погрешних стимулуса (BIJALISTOK і KREJK 2010: 20).

Ипак, испитивање когнитивног очувања и код младих одраслих билингвала не даје јасне резултате (PAP i GRINBERG 2013). То се објашњава ефектом плафона (енгл. ceiling effect), јер су у том добу когнитивне функције на врхунцу код свих здравих особа, па се њихово појачање не може пратити, или просто не могу више да напредују. Тренутно није могуће проценити ту разлику коју доноси билингвизам код ове специфичне узрасне групе, стога неки истраживачи сматрају да би морала да се спроведе детаљнија анализа индивидуалних профила билингвала, нарочито њихове употребе језика, да би докази о билингвалној предности у случају деменције и когнитивног старења били чвршћи (PORČ і KROT 2019; DEL MAŠIO, FEDELI i dr. 2018).

\section{5. Закључак}

У раду је представљен општи преглед релевантних истраживања о когнитивним предностима билингвизма. Најпре је дат осврт на погледе и ставове о билингвизму кроз историју и уочена је промена од негативног ка позитивном виђењу билингвизма, односно од тога да се сматрало да омета нормалан когнитивни и језички развој детета, до тога да заправо ојачава извршне функције као што су радна меморија, инхибиција и контрола пажње. Тако је кроз различите задатке (Струп, фленкер, задатак мреже пажње и сл.) утврђена такозвана предност билингвала, у смислу да имају могућност да инхибирају ометајућу језичку зарад циљне информације. Испитивања новорођенчади су чак предложила да се код билингвала паралелно активирају оба система и активно учествују приликом језичког процесирања.

Међутим, истакнути су и недостаци билингвала у односу на монолингвале у погледу неких лингвистичких компетенција, попут вербалне, односно лексичке флуентности, доживљавања ситуације „на врх језика”. Општи су закључци су следећи: ако се превазиђу флуентни недо- 
стаци, извршно функционисање ће бити доминантна предност код флуентнијих билингвала у односу и на монолингвале, и на мање флуентне билингвале.

У раду је представљен и осврт на скорашња преиспитивања тих билингвалних предности, која показују да постоје конфундирајући фактори у ранијим студијама, при чијем отклањању се не долази до истих позитивних резултата у корист билингвизма. Такође, позитивни резултати се доминатно јављају у истраживањима са мањим бројем испитаника, док на већем узорку нема релевантних резултата који би били снажан доказ за постојање билингвалне предности у погледу извршних функциja.

У последњем поглављу је дат краћи осврт на експерименте са старијим билингвалима и монолингвалима са деменцијом и у одређеним истраживањима показано је да билингвизам не спречава појаву деменције, али може да одложи њене симптоме за чак четири године. Међутим, како није могуће доћи до истих резултата на исти начин код потпуно здравих особа истог узраста, поједини истраживачи сматрају да је неопходна детаљнија анализа индивидуалних случајева и обухватније истраживање да би тврдња о билингвалној предности у каснијем животном добу била научно поузданија.

Евидентна је дебата у литератури о предностима билингвизма и наша је процена да се извесне предности билингвизма не могу спорити, нарочито у стварном животу, изван контролисаних екперимената (предности у случају деменције; креативно и дивергентно размишљање; толеранција према двосмислености...), али се морамо сагласити са скорашњим преиспитивањима која су показала недостатке у методолошком смислу, те би једино обухватнија и детаљнија истраживања не само улоге извршних функција него и профила билингвалних индивидуа или група дала бољи увид у њихов когнитивни статус у односу на монолингвалне испитанике.

\section{Цитирана литература}

ADESOPE, LAVIN i dr. 2010: Adesope, O. O., Lavin, T., Thompson, T., Ungerleider, C. A systematic review and meta-analysis of the cognitive correlates of bilingualism. Review of Educational Research, 80, 207-245.

BEST, MILER i dr. 2011: Best, J. R., Miller, P. H., Naglieri, J. A. Relations between executive function and academic achievement from ages 5 to 17 in a large, representative national sample. Learning and Individual Differences, 21, 327-336.

BIJALISTOK 1988: Bialystok, E. Levels of bilingualism and levels of linguistic awareness. Developmental Psychology, 24, 560-567. 
BIJALISTOK 1999: Bialystok, E. Cognitive complexity and attentional control in the bilingual mind. Child Development, 70, 636-644.

BIJALISTOK 2001: Bialystok, E. Bilingualism in development: Language, literacy, and cognition. New York: Cambridge University Press.

BIJALISTOK 2006: Bialystok, E. Effect of bilingualism and computer video game experience on the Simon task. Canadian Journal of Experimental Psychology, 60 (1), 68-79.

BIJALISTOK i FENG 2009: Bialystok, E., Feng, X. Language proficiency and executive control in proactive interference: Evidence from monolingual and bilingual children and adults. Brain and Language, 109, 93-100.

BIJALISTOK i KREJK 2010: Bialystok, E., Craik, F.I.M. Cognitive and linguistic processing in the bilingual mind, Current directions in psychological science, 19(1), 19-23.

BIJALISTOK, KREJK i dr. 2004: Bialystok, E., Craik, F.I.M., Klein, R., Viswanathan, M. Bilingualism, aging, and cognitive control: Evidence from the Simon task. Psychology and Aging, 19, 290-303.

BIJALISTOK, KREJK i dr. 2007: Bialystok, E., Craik, F.I.M., Freedman, M. Bilingualism as a protection against the onset of symptoms of dementia. Neuropsychologia, 45, 459-464.

BIJALISTOK, KREJK i dr. 2008a: Bialystok, E., Craik, F.I.M., Luk, G. Cognitive control and lexical access in younger and older bilinguals. Journal of Experimental Psychology: Learning, Memory, and Cognition, 34, 859-873.

BIJALISTOK, KREJK i dr. 2008b: Bialystok, E., Craik, F.I.M., Luk, G. Lexical access in bilinguals: Effects of vocabulary size and executive control. Journal of Neurolinguistics, 21, 522-538.

BIJALISTOK, KREJK i dr. 2013: Bialystok, E., Craik, F.I.M., Luk, G. Bilingualism: Consequences for mind and brain. Trends in Cognitive Sciences, 16(4), 240250.

BIJALISTOK i MARTIN 2004: Bialystok, E., Martin, M.M. Attention and inhibition in bilingual children: Evidence from the dimensional change card sort task. Developmental Science, 7, 325-339.

BIJALISTOK i ŠAPERO 2005: Bialystok, E., Shapero, D. Ambiguous benefits: The effect of bilingualism on reversing ambiguous figures. Developmental Science, 8, 595-604.

DARSI 1963: Darcy, N. Bilingualism and the measurement of intelligence: Review of a decade of research. The Journal of Genetic Psychology. 103 (2): 259-282.

DEL MAŠIO, FEDELI i dr. 2018: Del Maschio N., Fedeli D., Abutalebi J. Bilingualism and aging: Why research should continue. Linguist. Approaches Biling.

ENGEL DE ABRU 2011: Engel de Abreu, P.M. Working memory in multilingual children: Is there a bilingual effect? Memory, 19, 529-537.

GEC 2003: Goetz, P. The effects of bilingualism on theory of mind development. Bilingualism: Language and Cognition, 6, 1-15.

GUDENOU 1926: Goodenough, F.L. Racial differences in the intelligence of school children. Journal of Experimental Psychology, 9, 388-397.

HAKUTA i DIJAZ 1985: Hakuta K., Diaz R. M. The relationship between degree of 
bilingualism and cognitive ability: a critical discussion and some new longitudinal data. In Nelson K. E. Children's Language, vol.5. Erlbaum, 320-344.

HILČI i KLAJN 2011: Hilchey, M.D., Klein, R.M. Are there bilingual advantages on nonlinguistic interference tasks? Implications for the plasticity of executive control processes. Psychonomic Bulletin and Review, 18, 625-658.

JANKO-VORAL 1972: Ianco-Worrall, A. Bilingualism and cognitive development. Child Development, 43, 1390-1400.

KOVAČ i MELER 2009: Kovac, A.M., Mehler, J. Cognitive gains in 7-month-old bilingual infants. Proceedings of the National Academy of Sciences, 106(16), 6556-6560.

KOSTA, HERNANDEZ i dr. 2008: Costa, A., Hernandez, M., Sebastian-Galles, N. Bilingualism aids conflict resolution: Evidence from the ANT task. Cognition, 106, 59-86.

KRISTAL 1985: Kristal, D. Enciklopedijski rečnik moderne lingvistike. Beograd: Nolit. KROMDAL 1999: Cromdal, J. Childhood bilingualism and metalinguistic skills: Analysis and control in young Swedish-English bilinguals. Applied Psycholinguistics, 20, 1-20.

MAJKL i GOLAN 2005: Michael, E.B., Gollan, T.H. Being and becoming bilingual: Individual differences and consequences for language production. Handbook of bilingualism: Psycholinguistic approaches, New York: Oxford University Press, 389- 407.

MIJAKE i FRIDMAN 2012: Miyake, A., Friedman, N.P. The nature and organization of individual differences in executive functions: Four general conclusions. Current Directions in Psychological Science, 21, 8-14.

OKANDA, MORIGUČI i dr. 2010: Okanda, M., Moriguchi Y., Itakura S. Language and cognitive shifting: Evidence from young monolingual and bilingual children. Psychological Reports, 107, 68-78.

PAP 2019: Paap, K. R. The bilingual advantage debate: Quantity and quality of the evidence. In J. W. Schwieter (Ed). The Handbook of Neuroscience of Multilingualism (pp. 701-735). London: Wiley-Blackwell.

PAP i dr. 2017: Paap, K. R., Anders, R., Mikulinsky, R., Mason, L., \& Alvarado, K. More than 100 studies and 150 tests of the hypothesis that the differences between congruent and incongruent trials are smaller for bilinguals compared to monolinguals. Paper presented at the 58th Annual Meeting of the Psychonomic Society, Vancouver.

PAP i dr. 2015: Paap, K. R., Johnson, H. A., \& Sawi, O. Bilingual advantages in executive functioning either do not exist or are restricted to very specific and undeterminedcircumstances. Cortex, 69, 265-278. https://doi.org/10.1016/j. cortex.2015.04.

PAP i dr. 2014: Paap, K.R., Johnson, H.A., and Sawi, O. Are bilingual advantages dependent upon specific tasks or specific bilingual experiences? Journal of Cognitive Psychology 26 (6): 615-639.

PAP i GRINBERG 2013: Paap, K.R., Greenberg, Z.I. There is no coherent evidence for a bilingual advantage in executive processing. Cognitive Psychology, 66(2), $232-258$. 
PEAL i LAMBERT 1962: Peal, E., Lambert, W. The relation of bilingualism to intelligence. Psychological Monographs, 76, 1-23.

PORČ i KROT 2019: Poarch, G.J.; Krott, A. A bilingual advantage? An appeal for a change in perspective and recommendations for future research. Behav. Sci. 9, 95.

RUEDA i dr. 2004: Rueda, M.R., Fan, J., McCandliss, B.D., Halparin, J.D., Gruber, D.B., Lercari, L.P., Posner, M.I. Development of attentional networks in childhood. Neuropsychologia, 42, 1029-1040.

SEBASTIAN-GALES, ALBAREDA-KASTELOT i dr. 2012: Sebastian-Galles, N., Albareda-Castelott, B., Weikum, W.M., Werker, J.F. A bilingual advantage in visual language discrimination in infancy. Psychological Science, 23, 994999.

SEMJUEL i RUER BRAKIN 2018: Cultural Effects Rather Than a Bilingual Advantage in Cognition: A Review and an Empirical Study. Cognitive Science 42, 2313-2341.

STERN 2002: Stern, Y. What is cognitive reserve? Theory and research application of the reserve concept. Journal of the International Neuropsychological Society, $8(3), 448-460$.

ŽENG 2018: Zhang, M. An Overview of the Bilingual Advantage: History, Mechanisms, and Consequences, WUPJ, vol.6.

ZELAZO, FRAJ i dr. 1996: Zelazo, P.D., Frye, D., Rapus, T. An age-related dissociation between knowing rules and using them. Cognitive Development, 11, 37-63.

Ana Krstić

\section{AN OVERVIEW OF RELEVANT RESEARCH ON COGNITIVE ADVANTAGES OF BILINGUALISM}

The paper provides a basic overview of relevant research on the cognitive advantages of bilingualism. It has been noted that the views on bilingualism were initially negative, ie. that it was thought that it disrupted child's cognitive development, but was later said to have cognitive advantage, especially with regard to executive functions, such as inhibition and attentional control, as well as working memory. It has also been shown that bilingualism has a lasting positive impact on cognitive reserve in older age. The paper also presents a more recent opposite approach to the cognitive advantages of bilingualism, in which they are revaluated in the light of the relevance of results in larger sample studies.

Key words: bilingualism, cognitive advantages, linguistic competence, aging 